\title{
Perception of French, Belgian and Swiss accents by French and Belgian listeners
}

Philippe Boula de Mareüil ${ }^{1}$, Alice Bardiaux ${ }^{2}$

${ }^{1}$ LIMSI - CNRS, Orsay, France

${ }^{2}$ Université Catholique de Louvain - FNRS, Louvain-la-Neuve, Belgium

https://doi.org/10.36505/ExLing-2011/04/0011/000180

\begin{abstract}
This article addresses the perceptual identification of French regional accents by listeners from the Paris region and Belgium. It is based on the geographical localisation of about thirty speakers from seven French-speaking areas: Vendee (West of France), Languedoc (South of France), Alsace (East of France), Romand Switzerland, East, Centre and West of Belgium. Contrary to the speakers' age bracket (older or younger than 60) and speaking style (read or spontaneous speech), listeners' region of origin and speakers' degree of accentedness (also rated by the listeners) have a major effect. Confusions are frequent among the Belgian areas, but taken as a whole, the Belgian accent is remarkably well identified, especially by Belgian listeners. The Southern accent remains identified best.
\end{abstract}

Key words: perceptual dialectology, regional variation, French accents.

\section{Introduction}

The way of speaking conveys a series of information from which attitudes and representations are built in speakers' mind. It is subject to cross- and within-speaker variation, as exemplified by regional accents. However, recent work based on perceptual experiments showed that fine-grained identification of regional accents is a difficult task, whether in American English (Clopper and Pisoni 2004) or in French (Woehrling and Boula de Mareüil 2006; Woehrling 2009). In particular, it was shown that confusions are frequent within Western French accents and within Southern French accents, irrespective of listeners' Western/Southern place of residence.

The present article expands upon previous experiments to investigate how various factors may impact the perceptual rating and/or identification of regional accents from France, Belgium and Switzerland. Some of these factors, assumed to be relevant in accent perception (Labov 1972; Preston 1989) are listeners' geographic origin, speakers' age and speaking style.

A perceptual test was conducted, involving listeners from France and Belgium. Based on speech samples from three areas of France, three areas of Belgium and one area of Switzerland, the test included a rating task and an identification task. The experimental corpus, subjects and tasks are described in the following section. Results are then presented and briefly discussed.

ExLing 2011: Proceedings of 4th Tutorial and Research Workshop on Experimental Linguistics, 25-27 May, Paris, France 


\section{Experimental setup}

The experimental corpus is made up of speech material recorded in TreizeVents (Vendee, West of France, assumed to represent "standard" French), Douzens (Languedoc, South of France), Boersch (Alsace, East of France), Nyon (Canton de Vaud, Romand Switzerland), Liège (East of Belgium), Gembloux (Centre of Belgium) and Tournai (West of Belgium). The data were collected within the framework of the "Phonology of Contemporary French" (PFC) project (Durand et al. 2002). In each investigation point, four speakers were selected: one male and one female aged between 30 and 60 , one male and one female aged over 60 . For each speaker, a read sentence and an excerpt of spontaneous speech (of about 10 seconds each) were selected.

The 56 resulting stimuli were administered to 25 listeners from the Paris region and 25 listeners from French-speaking Belgium. The rating task consisted in evaluating the degree of accentedness on a $0-5$ scale $(0=$ no accent; 5 = very strong accent) and the identification task consisted in a 7-alternative forced-choice categorisation. The experiment was conducted through a web-based interface (available at http///www.audiosurf.org/ test_perceptif_cecile/).

\section{Results}

Average results for both listener groups are reported in Table 1. Degrees of accentedness are tabulated between square brackets. Identification scores are tabulated within the core of the confusion matrices.

On average, the accents were judged as rather strong (3.0/5 for French listeners and 2.7/5 for Belgian listeners). Even though the accents from Belgium were rated stronger by French listeners than by Belgian listeners, the overall difference is not significant between the degrees of accentedness assigned by the two groups of subjects, according to a $t$-test.

The average correct identification rate is 36\% for French listeners and $44 \%$ for Belgian listeners. Analyses of variance (ANOVAs) were performed on listeners' responses counted as right (1) or wrong (0) with the random factor Subject, the between-subject factor Group (French/Belgian) and two withinsubject factors: speakers' Age $( \pm 60$ years $)$ and speaking Style (read/spontaneous). There is no significant effect of speakers' Age and speaking Style, but there is here a significant effect of listeners' Group $[F(1$, $48)=9.59 ; p<0.01]$. A Degree of accentedness was also attributed to the stimuli by rounding the listeners' average ratings, but no stimulus received an average rating close to 0 . ANOVAs were thus conducted with a 5-level within-subject factor Degree of accentedness. This factor produced a major effect $[F(4,196)=51.9 ; p<0.001]$. Results are similar when ANOVAs are conducted separately for each listener group. 
Table 1.Degrees of accentedness [out of 5, between square brackets] and confusion matrices resulting from the answers of 25 listeners from (a) the Paris region and (b) Belgium..Percentages are given with respect to 200 answers. For each investigation point in $\mathrm{Ve}$ (ndee), $\mathrm{La}$ (nguedoc), $\mathrm{Al}$ (sace), $\mathrm{Sw}$ (itzerland) and Be(lgium), majority answers are highlighted in boldface.

(a)

\begin{tabular}{|c|c|c|c|c|c|c|c|}
\hline \multicolumn{8}{|c|}{ Results of French listeners } \\
\hline Origin & $\begin{array}{l}\text { Treize- } \\
\text { Vents }\end{array}$ & Douzens & Boersch & Nyon & Liège & Gembloux & Tournai \\
\hline $\begin{array}{l}\text { Treize-V. } \\
(\mathrm{Ve})[1.9]\end{array}$ & 38 & 5 & 13 & 10 & 16 & 11 & 8 \\
\hline $\begin{array}{l}\text { Douzens } \\
\text { (La) [4.8] }\end{array}$ & 6 & 90 & 1 & 2 & 1 & 0 & 1 \\
\hline $\begin{array}{l}\text { Boersch } \\
\text { (Al) [3.7] }\end{array}$ & 9 & 2 & 34 & 25 & 9 & 14 & 8 \\
\hline $\begin{array}{c}\text { Nyon } \\
\text { (Sw) [3.2] }\end{array}$ & 4 & 2 & 20 & 38 & 14 & 12 & 11 \\
\hline $\begin{array}{c}\text { Liège } \\
(\mathrm{Be})[3.0]\end{array}$ & 11 & 3 & 18 & 14 & 19 & 22 & 14 \\
\hline $\begin{array}{l}\text { Gembloux } \\
\text { (Be) [2.7] }\end{array}$ & 18 & 4 & 14 & 17 & 16 & 19 & 13 \\
\hline $\begin{array}{c}\text { Tournai } \\
(\mathrm{Be})[2.0]\end{array}$ & 28 & 3 & 14 & 10 & 13 & 20 & 13 \\
\hline
\end{tabular}

(b)

\begin{tabular}{|c|c|c|c|c|c|c|c|}
\hline \hline \multicolumn{7}{|c|}{ Results of Belgian listeners } \\
\hline $\begin{array}{c}\text { Answer } \\
\text { Origin }\end{array}$ & $\begin{array}{c}\text { Treize- } \\
\text { Vents }\end{array}$ & Douzens & Boersch & Nyon & Liège & Gembloux & Tournai \\
\hline $\begin{array}{c}\text { Treize-V. } \\
\text { (Ve) [2.1] }\end{array}$ & $\mathbf{3 7}$ & 12 & 10 & 6 & 10 & 19 & 6 \\
\hline $\begin{array}{c}\text { Douzens } \\
\text { (La) [4.2] }\end{array}$ & 15 & $\mathbf{7 3}$ & 8 & 2 & 1 & 0 & 1 \\
\hline $\begin{array}{c}\text { Boersch } \\
(\mathrm{Al})[2.8]\end{array}$ & 10 & 1 & $\mathbf{4 4}$ & 22 & 6 & 12 & 5 \\
\hline $\begin{array}{c}\text { Nyon } \\
(\mathrm{Sw})[3.1]\end{array}$ & 14 & 5 & 18 & $\mathbf{5 5}$ & 2 & 2 & 4 \\
\hline $\begin{array}{c}\text { Liège } \\
(\mathrm{Be})[2.7]\end{array}$ & 8 & 1 & 4 & 4 & $\mathbf{4 8}$ & 17 & 18 \\
\hline $\begin{array}{c}\text { Gembloux } \\
(\mathrm{Be})[2.4]\end{array}$ & 4 & 3 & 5 & 2 & 22 & $\mathbf{3 9}$ & 25 \\
\hline $\begin{array}{c}\text { Tournai } \\
(\mathrm{Be})[1.4]\end{array}$ & 23 & 6 & 4 & 2 & 9 & $\mathbf{3 6}$ & 20 \\
\hline \hline
\end{tabular}


Detailed results (given in Table 1) show that Douzens (Languedoc, here the only representative of the South of France) and Nyon (Switzerland) are identified best. The Liège, Gembloux and Tournai (Belgium) investigation points are often confused: their correct identification rate is $17 \%$ for French listeners and 36\% for Belgian listeners. Yet, counting any of these three answers as correct, the identification rate as Belgian is $49 \%$ for French listeners and $77 \%$ for Belgian listeners. Even though responses are not very precise, the Belgian accent is thus remarkably well recognised.

\section{Discussion}

This study suggests that five French accents can be distinguished satisfactorily in France and its periphery: Western (standard) French, Southern French, Alsatian, Swiss and Belgian. Interestingly, identification was not affected significantly by speakers' age and speaking style. Degree of accentedness, however, was an influential factor: stronger accents were better identified than milder accents. Also, listeners' geographic origin was an influential factor, whereas it was not in Woerhling and Boula de Mareüil's (2006) experiment, based on listeners from Paris and Marseilles. Work is in progress to relate the results achieved to the phonetic characteristics of the accents under investigation.

\section{Acknowledgements}

We are grateful to the leaders of the PFC project Jacques Durand, Bernard Laks and Chantal Lyche. Our thanks also go to Cécile Woehrling, who designed and analysed the experiment conducted in the Paris region.

\section{References}

Clopper C.G., Pisoni D.B. 2004. Some acoustic cues for the perceptual categorization of American English regional dialects. Journal of Phonetics 32, 111-140.

Durand, J., Laks, B., Lyche, C. 2002. La phonologie du français contemporain : usages, variétés et structure. In Pusch, C. D. and Raible, W. (eds.), Romance corpus linguistics - Corpora and spoken language, 93-106. Tübingen, Narr.

Labov, W. 1972. Sociolinguistic patterns, Philadelphia, University of Pennsylvania Press.

Preston, D.R. 1989). Perceptual dialectology, Dordrecht, Foris Publications.

Woehrling, C., Boula de Mareüil, Ph. 2006. Identification d'accents régionaux en français : perception et analyse, Revue PArole 37, 25-65.

Woehrling, C. 2009. Accents régionaux en français: perception, analyse et modélisation à partir de grands corpus, $\mathrm{PhD}$ thesis, Université Paris-Sud. 